\title{
SPRY4-IT1 Gene
}

National Cancer Institute

\section{Source}

National Cancer Institute. SPRY4-IT1 Gene. NCI Thesaurus. Code C98179.

This gene may play a role in melanoma pathology. 